Originally published as:

Kaulitz, D., Mihica, D., Dorna, J., Costa, M.R., Petersen, B., Niemann, H., Tönjes, R.R., Denner, J. Development of sensitive methods for detection of porcine endogenous retrovirus-C (PERV-C) in the genome of pigs (2011) Journal of Virological Methods, 175 (1), pp. 60-65.

DOI: 10.1016/j.jviromet.2011.04.017

This is an author manuscript.

The definitive version is available at: http://www.sciencedirect.com/ 


\title{
Development of sensitive methods for detection of porcine endogenous retrovirus-C (PERV-C) in the genome of pigs
}

\author{
Danny Kaulitz ${ }^{a}$, Debora Mihica ${ }^{a}$, Jens Dorna ${ }^{b}$, Michael Rodrigues Costa ${ }^{b}$, Björn Petersen ${ }^{c}$, Heiner \\ Niemann $^{c}$, Ralf R. Tönjes ${ }^{\mathrm{b}}$, Joachim Denner ${ }^{\mathrm{a}}$ \\ ${ }^{a}$ Robert Koch-Institute, Retrovirus Induced Immunosuppression, Berlin, Germany \\ b Paul-Ehrlich-Institute, Langen, Germany \\ ${ }^{c}$ Institute of Farm Animal Genetics, Friedrich-Loeffler-Institute (FLI), Mariensee, Germany
}

\begin{abstract}
Porcine endogenous retroviruses (PERV) represent a risk for xenotransplantation using pig cells, tissues or organs. PERV-A and PERV-B are present in the genome of all pigs and both infect human cells in vitro. PERV-C infects only pig cells and it is integrated in the genome of most, but not all pigs. Recombinants between PERV-A and PERV-C were described that infect human cells and replicate at high titres. To avoid such recombinations, PERV-C positive animals should not be used for breeding animals suited for xenotransplantation.
\end{abstract}

In order to detect PERV-C positive pigs, different methods were developed such as specific PCRs using different primers, a highly sensitive nested PCR and a real-time PCR allowing measurement of proviral copy numbers. The real-time PCR was found to be useful to discriminate between contamination and actual provirus copies. The PCRs were optimized and their sensitivity was determined. Screening can be started with PCR1, if the result is negative, PCR2 to PCR5 or the nested PCR should be used, if the result is positive, the real-time PCR should be used to exclude contaminations. All methods were used to evaluate the prevalence of PERV-C and to identify PERV-C free animals. Due to the risk of contamination with cells from other animals testing should be performed with blood cells, not with ear biopsies.

\section{Introduction}

Pig to human xenotransplantation is a promising approach to alleviate the shortage of human donor organs (Ekser and Cooper, 2010). Pigs were selected as the most suitable donor animals because of several advantages: (i) similarities in physiology, (ii) they can be modified genetically easily and cloned, (iii) their generation time is relatively short, (iv) their litters are large and (v) their breeding costs are low. Nevertheless there are three hurdles to overcome: immunological rejection, physiological compatibility and microbiological safety (Pierson, 2009). Transgenic and knock-out animals were generated to overcome hyperacute and acute rejection ( [Petersen et al., 2009] and [Klymiuk et al., 2010]). In terms of microbiological safety, most of the potentially zoonotic porcine viruses and other microorganisms can be eliminated by qualified pathogen-free breeding ( [Tucker et al., 2002] and [Denner, 2008a]). In contrast, porcine endogenous retroviruses (PERV) represent a particular risk. PERV-A and PERV-B are integrated in the genome of all pig strains, they are released from normal pig cells and infect human cells (Patience et al., 1997). Another PERV, PERV-C, infects only pig cells and is not present in all pigs, nevertheless its prevalence appears to be relatively high. In a previous study 176 from 181 (92\%) animals were found to harbor PERV-C in their genome (Dieckhoff et al., 2009).

Although PERV-C does not infect human cells and therefore does not represent a direct risk for xenotransplantation, recombinants between PERV-A and PERV-C have been described in pigs, that are able to infect human cells ( [Bartosch et al., 2004] and [Denner, 2008b]). These recombinant viruses were characterised by high virus titres compared to the parental PERV-A (Harrison et al., 2004) and they were found to behave as exogenous viruses integrating de novo into the genome of 
pig cells in some organs, mainly the spleen (Dieckhoff et al., 2007), but they were absent from the germ line. Since PERV-A/C are characterised by high titre replication and increasing titres after passaging on human cells due to genetic alterations in the LTR (Denner et al., 2003), a consensus statement of the International Xenotransplantation Association recommended not to use pigs harbouring PERV-C for xenotransplantation in order to avoid PERV-A/C recombinations (Denner et al., 2009). To select PERV-C free pigs, sensitive methods have to be used. To screen for PERV-C free animals in pig colonies different methods including (i) standard PCR methods using five different primer pairs, (ii) a sensitive nested PCR and (iii) a real-time PCR allowing estimation of the copy number and to detect contaminations are described.

\section{Materials and methods}

\subsection{Animals and DNA isolation}

Ear biopsies and blood samples were taken from 38 transgenic and non-transgenic pigs at the Friedrich Löffler Institute, Mariensee, and from German landrace pigs in animal farms near Frankfurt. Transgenic pigs were carrying either human heme oxygenase (hHO-1), human tumour necrosis factoralpha inducible gene A20 (hA20), human CD59, human decay-accelerating factor (DAF, CD55) or they were alpha 1,3 galactosyltransferase knockout (GalKO) pigs (Petersen et al., 2009). Animals were kept with an Ethical Committee approval and according to international standards for animal welfare.

Peripheral blood mononuclear cells (PBMCs) were isolated from blood samples using LSM 1077 lymphocyte separation medium (PAA, Pasching, Austria) and DNA was isolated using the DNeasy blood and tissue kit (Qiagen, Hilgen, Germany). DNA isolation from ear biopsies was performed using the same kit and the TissueLyser LT (40 s at $30 \mathrm{~Hz}$ ) (Qiagen).

\subsection{PCR and nested PCR}

In addition to the PCR based on primers published by Takeuchi et al. (1998) (designated PCR1) four other PCR setups were developed, based on different primer pairs (PCR2 to PCR5) (Fig. 1, Table 1). Furthermore, a nested PCR was developed, based on flanking primers identical to the primers used in PCR1 and inner primers identical to the primers used in PCR2 (Fig. 1, Table 1). Reactions were performed in a $25 \mu$ volume using the Kapa2G robust PCR Kit (Peqlab, Erlangen, Germany). The mixture consisted of $5 \mu \mathrm{l}$ of $5 \times$ PCR-Buffer A (final concentration $1.5 \mathrm{mM} \mathrm{MgCl}_{2}$ ), additional $0.5 \mu \mathrm{l}$ $\mathrm{MgCl}_{2}(25 \mathrm{mM}), 0.5 \mu \mathrm{ldNTPs}(10 \mathrm{mM}$ each dNTP), $1.25 \mu \mathrm{l}$ primer $(10 \mu \mathrm{M})$ each, $5 \mu \mathrm{l} 5 \times$ Enhancer I, $0.1 \mu \mathrm{l}$ of Kapa2G polymerase ( 5 units/ $\mu$ l) and $1-3 \mu$ template (100 ng DNA) filled up to $25 \mu \mathrm{l}$ with nuclease-free water. For the nested PCR $3 \mu$ of the first step PCR product were used. The flanking PCR was performed under following cycle conditions: $15 \mathrm{~min}$ of pre-incubation at $95^{\circ} \mathrm{C}$ and 30 cycles in three steps each $\left(94^{\circ} \mathrm{C}\right.$ for $30 \mathrm{~s}, 55^{\circ} \mathrm{C}$ for $30 \mathrm{~s}, 72^{\circ} \mathrm{C}$ for $30 \mathrm{~s}$ ) and $72{ }^{\circ} \mathrm{C}$ for $5 \mathrm{~min}$. Cycle conditions for the inner PCR were 3 min of pre-incubation at $94^{\circ} \mathrm{C}$ and 30 cycles in three steps $\left(94^{\circ} \mathrm{C}\right.$ for $30 \mathrm{~s}, 63^{\circ} \mathrm{C}$ for $40 \mathrm{~s}, 72^{\circ} \mathrm{C}$ for $30 \mathrm{~s}$ ) and $72^{\circ} \mathrm{C}$ for $10 \mathrm{~min}$. Both PCRs were performed using $100 \mathrm{ng}$ DNA from the pig cell line PK15 as a competitor.

\subsection{Real-time PCR}

For quantitation of envC-specific proviral DNA the primers real-time for and real-time rev (Table 1, Fig. 1) were designed. A duplex real-time PCR was performed based on cyclophilin (cyp) as reference gene using the primers cyp real-time for and cyp real-time rev and quantifying the PCR with a cyp probe (Table 1). The $25 \mu \mathrm{l}$ reaction mixture consisted of $2.5 \mu \mathrm{l} 10 \times \mathrm{PCR}$ buffer $(100 \mathrm{mM}$ Tris- $\mathrm{HCl}$, $500 \mathrm{mM} \mathrm{KCl}, 15 \mathrm{mM} \mathrm{MgCl} 2,0.01 \%$ (w/v) gelatin), $3 \mu \mathrm{l} \mathrm{MgCl}_{2}(25 \mathrm{mM}), 0.5 \mu \mathrm{ldNTP}(20 \mathrm{mM}), 0.5 \mu \mathrm{l}$ $(10 \mu \mathrm{M})$ of each primer, $0.5 \mu \mathrm{l}$ of both probes $(10 \mu \mathrm{M}), 0.1 \mu \mathrm{l}$ ROX (Invitrogen, Darmstadt, Germany), $0.3 \mu \mathrm{l}$ AmpliTaq Gold ${ }^{\otimes}$ polymerase (Roche, Mannheim, Germany) $(5 \mathrm{U} / \mu \mathrm{l})$, nuclease free water and the template DNA $(100 \mathrm{ng})$. The thermal cycling conditions used were $7 \mathrm{~min}$ at $95^{\circ} \mathrm{C}$ followed by 50 cycles of $95^{\circ} \mathrm{C}$ for $20 \mathrm{~s}$ and $58^{\circ} \mathrm{C}$ for $30 \mathrm{~s}$ in a Stratagene MX4000 machine, the quantitative real-time PCR software was used (Agilent, Waldbronn, Germany). Efficacy was calculated by measuring ten fold serial dilutions of genomic envC positive DNA from $1.1 \times 10^{10}$ to 0.2 plasmid copies per reaction. 
Amplicons generated by real-time PCR were subcloned into the vector pBluescript II KS (Agilent, Waldbronn, Germany), sequenced and the plasmid was used in the real-time PCR to measure the copy numbers.

\subsection{Sequencing}

Amplicons generated by PCR3 as indicated in Fig. 1 were sequenced bidirectionaly using Sanger's dideoxy method, using $10 \mathrm{ng}$ of amplicon, $5 \mathrm{pmol}$ of primer, $1 \mu \mathrm{l}$ of $5 \times$ Buffer $2 \mu \mathrm{l}$ of BigDye (Applied Biosystems), and the corresponding primers.

\section{Results}

\subsection{Characterisation and sensitivity of the PCR and nested PCR}

To screen animals for PERV-C provirus integration, a standard PCR (PCR1) was used, employing the differences in the sequences in the receptor-binding site between PERV-A, PERV-B and PERV-C (Takeuchi et al., 1998) (Fig. 1). The sensitivity of the PCR1 was estimated to be $1.1 \times 10^{4}$ copies per genome using the molecular clone PERV-C(1312) (Preuss et al., 2006) (Fig. 2A). To increase the sensitivity of nucleic acid amplifications, a nested PCR was developed, using flanking primers identical to the primers used in PCR1 and two inner primers. The sensitivity of the nested PCR was estimated by serial dilutions to be $1-0.6$ copies per genome using molecular clone PERV-C(1312) in the presence of DNA from the pig cell line PK15 (Fig. 2B). To exclude false-negative results due to mutations in the primer binding sites, three additional PERV-C-specific PCRs such as PCR2, using the inner primers of the nested PCR, PCR3, PCR4 and PCR 5 were developed (Table 1, Fig. 1).

When DNA samples from 38 transgenic and non-transgenic pigs were analysed, 35 of them (92\%) were positive in PCR1, 2 and 3 (Table 2), indicating that the PCRs gave the same result and that these animals were PERV-C positive. PCR4 was not applied knowing that it gives the same result as PCR1 (Dieckhoff et al., 2009). When DNA from 8 animals were tested using PCR5, the results were the same as obtained with PCR1-3.

When the DNA from animals negative for PERV-C according to PCR1-3 were analysed using the highly sensitive nested PCR, the results remained negative. However, when ear biopsies and blood from the same animal were tested using the nested PCR, in some cases DNA from ear biopsies was positive whereas DNA from PBMCs was negative for PERV-C proviruses. The reason for the false positive results was certainly the presence of cells from neighbour animals on the skin of the animals or contaminations by the instrument used to take the biopsies (this will be confirmed below by realtime PCR). Since the contamination was low and not detected by standard PCR, these results also underline the high sensitivity of the nested PCR.

\subsection{Characterisation and sensitivity of the real-time PCR}

To quantify the number of integrated PERV-C proviruses, a real-time PCR was established. Primers and a probe were designed in a region specific for PERV-C (Fig. 1, Table 1). To achieve optimal conditions the size of the amplicon was kept small (92 bp). As an internal standard for quantitation and for quality control of the template DNA a part of the house keeping gene cyclophilin was co-amplified. There was no interference between both real-time PCRs as confirmed by an analysis of serial dilutions of genomic DNA from one pig, which was PERV-C positive. The PCR showed an efficacy of $93.7 \%$ for cyclophilin and $99.3 \%$ for envPERV-C (Fig. 3). The detection limit of the real-time PCR was 100 copies as determined by a plasmid standard and a linear co-amplification was obtained between $1 \mathrm{pg}$ to $100 \mathrm{ng}$ of genomic template DNA. 


\subsection{Screening for PERV-C negative animals}

In total, 38 transgenic and non-transgenic landrace pigs from different sources were analysed using standard PCR, nested PCR and the real-time PCR. As shown above, 35 of 38 animals were tested positive by PCR1, PCR2 and PCR3 (Table 2). When the DNA from the PERV-C positive animals was analysed by real-time PCR, the signals for PERV-C and cyclophilin (cyp) appeared at the same cycle threshold value (ct-value approximately 25, Fig. 3). Real-time PCR was also used to analyse DNA from ear biopsies and DNA from PBMCs which gave varying results in the nested PCR. Both DNA samples originated from the same animal (see above). In case of DNA originating from ear biopsies the ct-value of the PERV-C signal was much higher compared to the ct-value of cyclophylin (between 35 and 40 compared to 25, Fig. 3), indicating that there is less than one copy per genome. At the same time real-time PCR of the DNA from PBMCs confirmed the absence of PERV-C. This indicates that PERV-C is not endogenous in these animals and therefore represents a contamination, possibly by cells from neighbour PERV-C positive pigs or by a contamination due to the instrument used for taking biopsies. This means, the real-time method may also be used to discriminate between contaminations with DNA or cells from PERV-C positive animals on the one hand and presence of an integrated endogenous provirus on the other hand. Calculation of copy numbers revealed 1 to 7 PERV-C copies per genome in PERV-C positive animals and less than 1 copy in 300 genomes in the case of contaminations.

\subsection{Confirmation by sequencing}

Genomic DNA from PERV-C positive animals (three transgenic animals and two farm pigs) were amplified using PCR3 and the amplification products were sequenced. As a result, the sequences were found identical to the sequences shown in Fig. 1, indicating that the proviral PERV-C sequences were identical at least in this region.

\section{Discussion}

Different methods were developed to screen for the presence of PERV-C proviruses in the genome of farm pigs and of transgenic pigs bred for xenotransplantation. These methods include five standard PCR using different primer pairs, a nested PCR and a real-time PCR. Using these methods, 35 of 38 $(92 \%)$ non-transgenic and transgenic animals were found to carry PERV-C in their genome, confirming a previous study in which 176 of 181 animals (92\%) were PERV-C positive (Dieckhoff et al., 2009). The transgenic animals studied here expressed different genes that should reduce hyperacute and vascular rejection such as hHO-1, hA20, CD59, DAF or represent GalKO knockout animals (Table 2). Although the number of PERV-C negative pigs is low, these animals can be used as source for genetically modified animals designed for xenotransplantation.

Since it was recommended not to use animals harbouring PERV-C in their genome in order to avoid PERV-A/C recombinations (Denner et al., 2009), these methods are instrumental for the detection of PERV-C free animals. PERV-A/C were until now detected only in miniature pigs and in these animals only in certain organs, e.g., in the spleen, but not in other organs and never in the germ line ( [Bartosch et al., 2004], [Harrison et al., 2004] and [Dieckhoff et al., 2007]). PERV-A/C were also not found in the New Zealand designated pathogen-free herd (Garkavenko et al., 2008). However, there are new reports on PERV-A/C in commercially used pigs with an increased number in clinically affected animals (Pal et al., 2011). In addition, there are also other reasons not to use PERV-C positive animals. First, the ability of PERV-C to infect cells that do not harbor the specific receptor by receptor-independent infection (Lavillette and Kabat, 2004), and second, mutations in the envelope protein of PERV-C may change the tropism towards human cells (Gemeniano et al., 2006). These data indicate, that breeding out PERV-C will reduce the risk of PERV transmission in xenotransplantation.

The methods are sensitive to detect up to $1.1 \times 10^{3}$ copies per genome in the standard PCR 1,1 copies per genome in the nested PCR and 100 molecules in the real-time PCR. The use of such sensitive methods may always be associated with the risk of contaminations and false positive results. Accordingly, a high risk of contamination was observed, when ear biopsies were used, either due to cells originating from other animals on the ear of the tested animal or on the instrument used for taking 
the biopsy. In general, a high sensitivity and at the same time a high specificity are important for the detection of retroviral infections. Recent reports showing infection with a murine retrovirus, XMRV (xenotropic murine leukemia virus-related virus), in patients with prostate carcinoma and chronic fatigue syndrome (CFS) as well as in healthy individuals in some laboratories in the USA, but not in Europe (for review see Denner, 2010) are an example underlining this requirement. At present there is overwhelming evidence that the detection of XMRV or other murine viruses in human tissues represents the result of laboratory contaminations by murine DNA or cells (Smith, 2010). Therefore, PCRs designed to detect retrovirus infections or proviruses of endogenous retroviruses should be performed under appropriate conditions and all necessary precautions should be undertaken.

Based on these results, for an effective screening for PERV-C in pigs the use of blood samples (not ear biopsies, to avoid contaminations with cells from PERV-C positive animals) is recommended. The screening should start with PCR analyses such as PCR1. If the result is negative, mutations in the primer binding may be the reason and in this case PCR2 to PCR5 should be used. If PCR1 gives a positive result, a real-time PCR has to be performed to test for contamination in order to avoid falsepositive results. If PCR1 to PCR5 give a negative result, a nested PCR or the real-time PCR should be performed to detect animals with low copy numbers of PERV-C.

\section{Acknowledgement}

This work was supported by the Deutsche Forschungsgemeinschaft (DFG Transregio Research Unit FOR 535).

\section{References}

Bartosch, B., Stefanidis, D., Myers, R., Weiss, R., Patience, C., Takeuchi, Y., 2004. Evidence and consequence of porcine endogenous retrovirus recombination. J. Virol. 78, 13880-13890.

Denner, J., 2008a. Xenotransplantation: state of the art of biosafety. In: Jansen, E.S., Simon, J.W. (Eds.), Xenotransplantation-Ethic, Economic, Social cultural and Scientific background, vol. 1. VDMVerlag, Saarbrücken, pp. 7-79.

Denner, J., 2008b. Recombinant porcine endogenous retroviruses (PERV-A/C): a new risk for xenotransplantation? Arch. Virol. 153, 1421-1426.

Denner, J., 2010. Detection of a gammaretrovirus XMRV, in the human population: open questions and implications for xenotransplantation. Retrovirology $7,16$.

Denner, J., Specke, V., Thiesen, U., Karlas, A., Kurth, R., 2003. Genetic alterations of the long terminal repeat of an ecotropic porcine endogenous retrovirus (PERV) during passage in human cells. Virology 314, 125-133.

Denner, J., Schuurman, H., Patience, C., 2009. The International Xenotransplantation Association consensus statement on conditions for undertaking clinical trials of porcine islet products in type 1 diabetes-Chapter 5: strategies to prevent transmission of porcine endogenous retroviruses.

Xenotransplantation 16, 239-248.

Dieckhoff, B., Puhlmann, J., Büscher, K., Hafner-Marx, A., Herbach, N., Bannert, N., Büttner, M., Wanke, R., Kurth, R., Denner, J., 2007. Expression of porcine endogenous retroviruses (PERVs) in melanomas of Munich miniature swine (MMS) Troll. Vet. Microbiol. 123, 53-68.

Dieckhoff, B., Kessler, B., Jobst, D., Kues, W., Petersen, B., Pfeifer, A., Kurth, R., Niemann, H., Wolf, E., Denner, J., 2009. Distribution and expression of porcine endogenous retroviruses in multitransgenic pigs generated for xenotransplantation. Xenotransplantation 16, 64-73.

Duvigneau, J.C., Hartl, R.T., et al., 2005. Quantitative simultaneous multiplex realtime PCR for the detection of porcine cytokines. J. Immunol. Methods 306, 16-27.

Ekser, B., Cooper, D.K., 2010. Overcoming the barriers to xenotransplantation: prospects for the future. Expert. Rev. Clin. Immunol. 6, 219-230.

Garkavenko, O., Wynyard, S., Nathu, D., Simond, D., Muzina, M., Muzina, Z., Scobie, L., Hector, R.D., Croxson, M.C., Tan, P., Elliott, B.R., 2008. Porcine endogenous retrovirus (PERV) and its transmission characteristics: a study of the New Zealand designated pathogen-free herd. Cell Transplant. 17, 1381-1388.

Gemeniano, M., Mpanju, O., Salomon, D.R., Eiden, M.V., Wilson, C.A., 2006. The infectivity and host range of the ecotropic porcine endogenous retrovirus PERV-C, is modulated by residues in the Cterminal region of its surface envelope protein. Virology 346, 108-117. 
Harrison, I., Takeuchi, Y., Bartosch, B., Stoye, J.P., 2004. Determinants of high titer in recombinant porcine endogenous retroviruses. J. Virol. 78, 13871-21389.

Klymiuk, N., Aigner, B., Brem, G., Wolf, E., 2010. Genetic modification of pigs as organ donors for xenotransplantation. Mol. Reprod. Dev. 77, 209-221.

Lavillette, D., Kabat, D., 2004. Porcine endogenous retroviruses infect cells lacking cognate receptors by an alternative pathway: implications for retrovirus evolution and xenotransplantation. J. Virol. 78, 8868-8877.

Pal, N., Baker, R., Schalk, S., Scobie, L., Tucker, A.W., Opriessnig, T., 2011. Detection of porcine endogenous retrovirus (PERV) viremia in diseased versus healthy US pigs by qualitative and quantitative real-time RT-PCR. Transbound. Emerg. Dis., doi:10.1111/j.1865-1682.2011.01210.x. Patience, C., Takeuchi, Y., Weiss, R.A., 1997. Infection of human cells by an endogenous retrovirus of pigs. Nat. Med. 3, 282-286.

Petersen, B., Carnwath, J.W., Niemann, H., 2009. The perspectives for porcine-tohuman xenografts. Comp. Immunol. Microbiol. Infect. Dis. 32, 91-105.

Pierson 3rd, R.N., Dorling, A., Ayares, D., Rees, M.A., Seebach, J.D., Fishman, J.A., Hering, B.J., Cooper, D.K., 2009. Current status of xenotransplantation and prospects for clinical application.

Xenotransplantation 16, 263-280.

Preuss, T., Fischer, N., Boller, K., Tönjes, R.R., 2006. Isolation and characterization of an infectious replication-competent molecular clone of ecotropic porcine endogenous retrovirus class C. J. Virol. 80 , 10258-10261.

Smith, R.A., 2010. Contamination of clinical specimens with MLV-encoding nucleic acids: implications for XMRV and other candidate human retroviruses. Retrovirology 7, 112.

Takeuchi, Y., Patience, C., Magre, S., Weiss, R.A., Banerjee, P.T., Le Tissier, P., Stoye, J.P., 1998. Host range and interference studies of three classes of pig endogenous retrovirus. J. Virol. 72, 99869991.

Tucker, A., Belcher, C., Moloo, B., Bell, J., Mazzulli, T., Humar, A., Hughes, A., McArdle, P., Talbot, A., 2002. The production of transgenic pigs for potential use in clinical xenotransplantation: baseline clinical pathology and organ size studies. Xenotransplantation 9, 203- 208. 


\section{Tables and Figures}

Table 1. Primers and probes used for amplification in the nested PCR and real-time PCR.

\begin{tabular}{|c|c|c|c|}
\hline Primeriprobe & Sequence $5^{\prime}-3^{\prime}$ & Location & $\begin{array}{l}\text { Accession } \\
\text { nos. }\end{array}$ \\
\hline $\begin{array}{l}\text { PCR1 = nested outer } \\
\text { for }\end{array}$ & $\begin{array}{l}\text { CTGACCTGGATTAGAACTGG } \\
\text { (Takeuchi et al. (1998)) }\end{array}$ & $6606 \ldots 6625$ & AM229312 \\
\hline $\begin{array}{l}\text { PCR1 = nested outer } \\
\text { rev }\end{array}$ & $\begin{array}{l}\text { ATGTTAGAGGATGGTCCTGG } \\
\text { (Takeuchi et al. (1998)) }\end{array}$ & $6867 \ldots 6886$ & AM229312 \\
\hline $\begin{array}{l}\text { PCR2 = nested inner } \\
\text { for }\end{array}$ & GTGCTCTCCTTCAGACCTAGATTAC & $6635 \ldots 6659$ & Am229312 \\
\hline $\begin{array}{l}\text { PCR2 = nested inner } \\
\text { rev }\end{array}$ & CGTCARGACCGTATTTGGTCC & $6822 \ldots 6842$ & AM 229312 \\
\hline PCR3 for & CTGACCTGGATTAGARCTGG & $6606 \ldots 6625$ & AM 229312 \\
\hline PCR3 rev & A.gTTTTGCCCCCATTTTAGT & $6924 \ldots 6944$ & AM229312 \\
\hline PCR4 = envC. 2 for & GATTAGARCTGGARGCCCCAAGTGCTCT & $6614 \ldots 6641$ & AM229312 \\
\hline PCR4 = envC.2 rev & TCTGATCCAGAAGTTATGTTAGAGGATGGT & $6872 \ldots 6901$ & AM229312 \\
\hline PCR5 for & СTATTCGCCTCARARTARACCAG & $6778 \ldots 6800$ & AM229312 \\
\hline PCR5 rev & CATGTGCATTGGTCTCTATG & $7086 \ldots 7105$ & AM229312 \\
\hline pCyp real-time for & TGCTTTCACAGARTARTTCCAGGATTTA & \multicolumn{2}{|c|}{ Duvigneau et al. (2005) } \\
\hline pCyp real-time rev & GACTTGCCACCAGTGCCATTA & \multicolumn{2}{|c|}{ Duvigneau et al. (2005) } \\
\hline pCyp probe & Cy5-TGCCaGGGTGGTGACTTCACACGCC-BHQ2 & \multicolumn{2}{|c|}{ Duvigneau et al. (2005) } \\
\hline envc real-time for & CCCCAaccCasgGaccag & $6853 \ldots 6870$ & AM229312 \\
\hline envc real-time rev & AMGTTTTGCCCCCATTTTAGT & $6924 \ldots 6944$ & AM229312 \\
\hline envc real-time probe & FAM-СTCTARСАTARСTCTGGATCAGACCC-BHQ1 & $6878 \ldots 6904$ & AM 229312 \\
\hline
\end{tabular}

Table 2. Incidence of PERV provirus in nontransgenic and transgenic pigs.

\begin{tabular}{|c|c|c|c|c|c|c|c|}
\hline $\begin{array}{l}\text { Number } \\
\text { of }\end{array}$ & Pig strain & $\begin{array}{l}\text { Origin of } \\
\text { the animals }\end{array}$ & $\begin{array}{l}\text { Transgene, } \\
\text { knockout }\end{array}$ & $\begin{array}{l}\text { PCR } \\
1\end{array}$ & $\begin{array}{l}\text { PCR } \\
2\end{array}$ & $\begin{array}{l}\text { PCR } \\
3\end{array}$ & $\begin{array}{l}\text { So } \\
\text { PERV-C }\end{array}$ \\
\hline animals & & & & & & & positive \\
\hline 16 & German landrace & $\begin{array}{l}\text { Farm } \\
\text { Frankfurt }\end{array}$ & none & $14 / 16$ & $14 / 16$ & $14 / 16$ & 87.5 \\
\hline 15 & $\begin{array}{l}\text { German landrace } \\
\text { German } \\
\text { landrace } \times \text { Duroc } \times \text { Minipig }\end{array}$ & $\begin{array}{l}\text { FLI } \\
\text { Mariensee } \\
\text { FLI } \\
\text { Mariensee }\end{array}$ & $\begin{array}{l}\mathrm{HO}-1, \mathrm{~A} 2 \mathrm{O}, \\
\text { CD59, DAF } \\
\text { GalKO }\end{array}$ & $\begin{array}{l}14 / 15 \\
7 \pi\end{array}$ & $\begin{array}{l}14 M 5 \\
7 \pi\end{array}$ & $\begin{array}{l}14 M 5 \\
77\end{array}$ & $\begin{array}{l}93.3 \\
100\end{array}$ \\
\hline
\end{tabular}

For details of the strains, the origin of the animals, the transgenes or GalKO, and the different PCR methods (PCR 1-PCR3) see Section 2 and Fig. 1. 
Figure 1. (A) Schematic presentation of the location of the primers for the PCRs and the probe for the real-time PCR. The length of the amplicons in bp and the approximate localisation of the virus receptor domain $A(V R A)$ and $B(V R B)$ and the proline rich region (PRR) in the receptor binding site of the surface envelope protein of PERV-C are indicated. (B) Sequence comparison of part of the surface envelope protein of PERV-C (envC), PERV-A (envA) and PERV-B (envB). The sequences of the outer primers (PCR1) and inner primers (PCR2) of the nested PCR, primers of PCR 3,4 and 5 as well as primers and probes of the real-time PCR are indicated.

A PCR1 (Takeuchi et al., 1998)

PCR2

PCR3

PCR4

PCR5

Real-time PCR

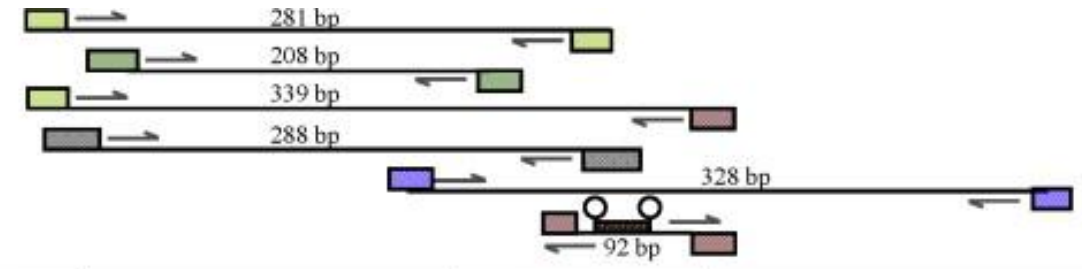

\begin{tabular}{|c|c|c|c|}
\hline VRA & VRB & PRR & \\
\hline$\prod_{6400}^{1}$ & $\prod_{6600}^{1}$ & $\underbrace{1}_{6800}$ & $\underbrace{1}_{7000}$ \\
\hline
\end{tabular}

$B$ envc 6577 envA 6675 envB 6592

enve 6637

envA 6745

envB 6641

$\begin{array}{ll}\text { envC } & 6681 \\ \text { envA } & 6815 \\ \text { envB } & 6685\end{array}$

$\begin{array}{ll}\text { envC } & 6751 \\ \text { enva } & 6886\end{array}$

$\begin{array}{ll}\text { envA } & 6886 \\ \text { envB } & 6754\end{array}$

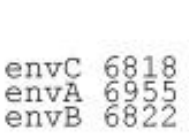

enve 6874

envA 7011

envc 6907

envA 7059

envC 6962

envA 7114

envB 7032

envC 7032

envA 7184

envC 7102

envA 7254
envB 7172
CCTATACCAGCTCTGGACAATTIAATTA----CCTGACCTGGATTAGAACTGGAAGCCCCAAGT------

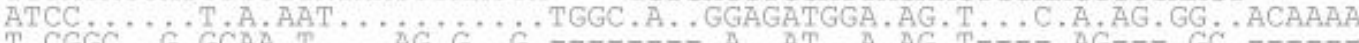

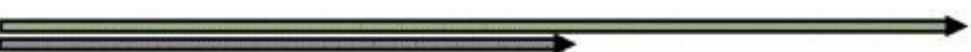

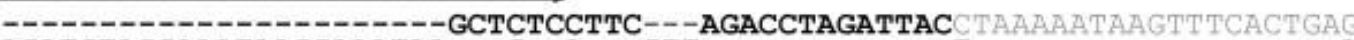
AGATGTACGAAATAAGCAAATAA, ..G A .

AAAGGAAAACAAGAAAATATCCTAAAATGGGTAAATGGTATGTCTTGGGGAATGGTATATTATGGAGGCT

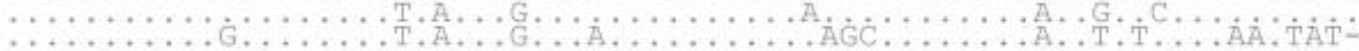
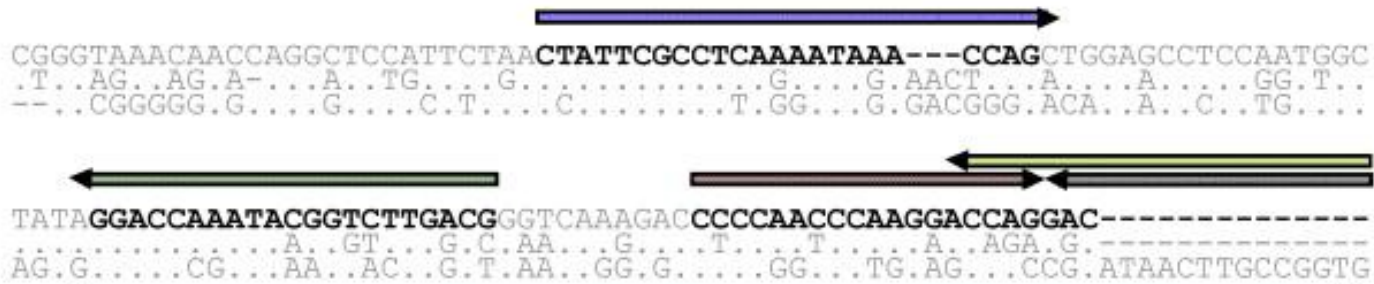

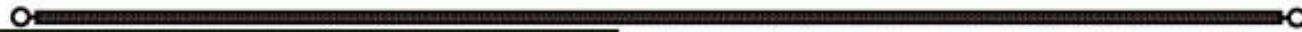
CATCCTCTAAC--------0

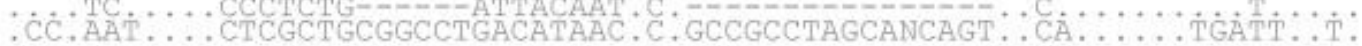

CTGA---GTCTAACA-

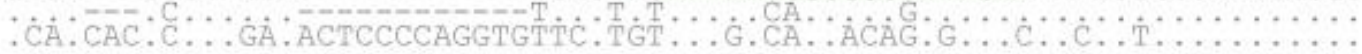

AGCTTTMCAAGCTCTTAACTCCACGACTCCAGAGGCTACCTCTTCTTGTTGGCTATGCTTGGCTTCGGGC

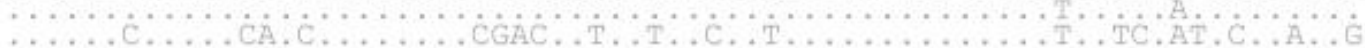

CCACCTTACTATGAAGGAATGGCTAGAAGAGGGAATTCAATGTGACAAAAGA CATAGAGACCAATGCA

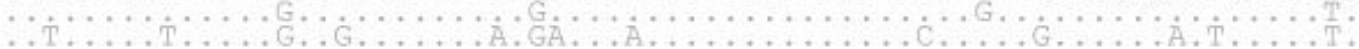

CATG GGATCCCAAAATARGCTTACCCTTACTGAGGTTCTGGAAAAGGCACCTGCATAGGAAAGGTTCC CATG 
Figure 2. Determination of PERV-C copies in plasmid molecules. The sensitivity of plasmid molecules of molecular clone PERV-C(1312) (Preuss et al., 2006) was estimated. (A) Standard PCR (PCR1); (B) nested PCR using outer primers (PCR1) and inner primers (PCR2). Each sample contains $100 \mathrm{ng}$ DNA of pig cell line PK15 as competitor. Negative control means water plus PK15 DNA; M, molecular marker.
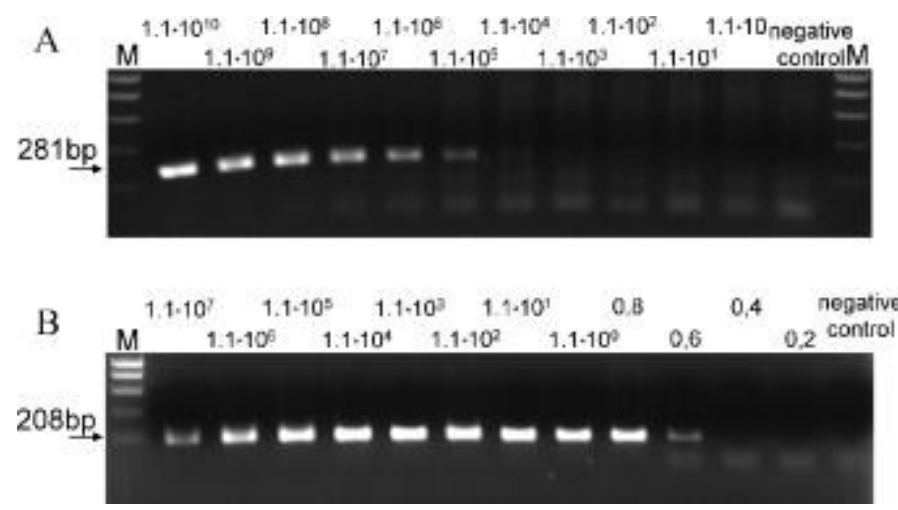

Figure 3. (A) Estimation of the efficacy of the duplex real-time PCR. Dilutions of the PERV-C env clone (99.3\% efficacy) and of a cyclophiline plasmid (93.7\% efficacy) were measured. (B) and (C) Results of the real-time PCR amplification of cyclophiline (B) and PERV-C env (C). All control PCR (B, cyclophiline, Cy5-signal) showed a ct-value of approximately 29, in the PERV-C measurement (C, FAM-signal) most samples showed endogenous PERV with a ct-value of 29, some samples showed contaminations with higher ct-values.
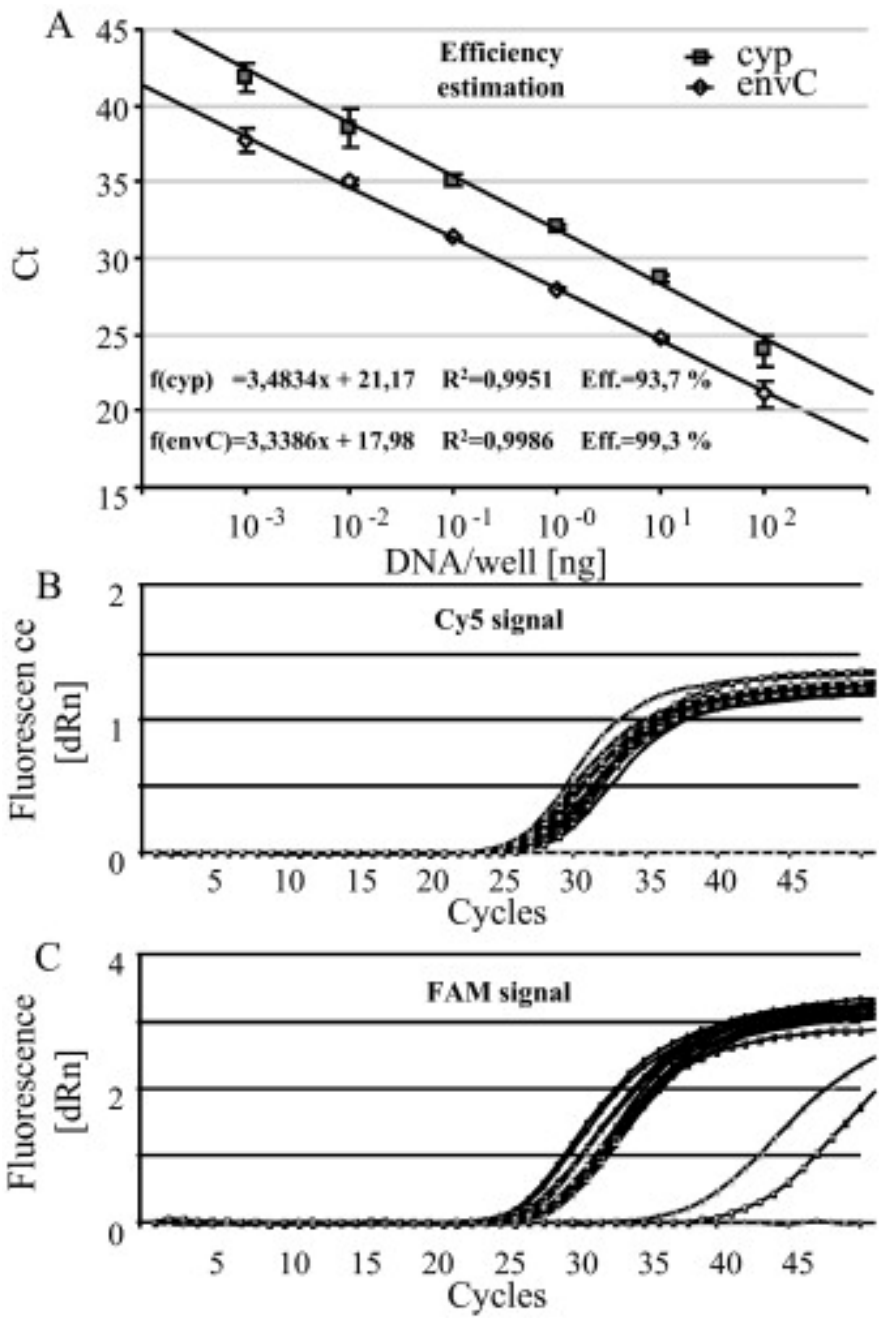